ever, the main questions which the commissioners had to answer were not easy. They were: (I) Are the nickel deposits of Ontario of such a character that this province can compete successfully as a nickel producer with any other country? (2) Can nickel be economically refined in Ontario? When they took up their work they were faced with the opinion of the companies interested that the answer to the latter question was in the negative. They also found that "for nearly fifteen years the whole of the great and highly profitable industry connected with the production of refined nickel from the vast deposits of nickel-copper ores in the Sudbury district has been divided between two powerful corporations. Both companies mine, smelt, and refine their own ore, and possess their own process of refining; both produce their refined metal product outside of Canada, and neither is a Canadian company. Other companies, British, American, and Canadian, some of them with excellent promise of success, have operated mines, erected plants, or have been otherwise engaged in the industry. In no case has any of their undertakings been permanent or successful." They had also to reckon with the fact that there is no certainty that large profits can be made every year from the nickel industry. It is neither a necessity of life nor an article of universal consumption or use. Its uses may be classified under four headings: $(x)$ as a component of alloys; (2) as a surface coating for other metals; (3) as a chemical or catalytic reagent; (4) as a pure metal. In the past the output has had to be curtailed at times.

In spite of these facts, the commissioners have had "no hesitation" in answering both the above questions in the affirmative. They say that the nickel deposits of Ontario are much more extensive and offer better facilities for the production of nickel at low cost than do those of any other country. Nickel-bearing ores occur in many parts of the world, but the great extent of the deposits in this province, their richness and uniformity of metal contents, and the success of the industry point strongly to the conclusion that Ontario nickel has little to fear from competition. They say also that any of the processes now in use for refining nickel could be successfully worked in Ontario, and conditions and facilities are at least as good in this province as in any other part of Canada. There is now an "assured prospect" of the erection in Ontario of two large plants for the refining of nickel--one by the International Nickel Co. of Canada at Port Colborne (Lake Erie), and the other by the British America Nickel Corporation, probably at Sudbury. The latter company, in which the British Government is a large shareholder, has been formed since the outbreak of the war. For special reasons the Mond Nickel Co. will continue to refine at $\mathrm{Clydach}$, near Swansea. In its business the manufacture of copper sulphate is almost as important as that of nickel, and this is marketed chiefly at Mediterranean ports.

No. 2508, VOL. IOO]

\section{STUDIES IN INFANT AND CHILD MORTALITY.}

$\mathrm{T}$ view of the importance which must be ascribed at the present time to the saving of child life (see Nature, October 26, p. I46), the Medical Research Committee has been well advised to institute an inquiry into the causes of death in infancy and childhood. The results of this inquiry have now been published in a series of essays, ${ }^{1}$ which, it is pointed out in an introduction, have been written primarily with a view to the planning of future lines of research rather than for publication as finished reports.

An introductory historical note is contributed by Dr. Chalmers, in which he remarks that deliberate effort to conserve infant life can be said only to have begun with the recognition of the contrast which the movement in the death-rate of infants presents when compared with that of the general death-rate. Whereas the latter fell continuously and considerably during the fourth quarter of the last century, fluctuations of the infant-mortality rate remained fairly constant and without very marked indication of a corresponding decrease.

The first report, by Dr. Brend, deals with the relative importance of pre-natal and post-natal conditions as causes of infant mortality. ${ }^{2} \mathrm{He}$ concludes that under the term "infant mortality" we are classing together two radically different types of deaths, which are brought about by different causes and are governed by different influences. The first type consists of deaths due to developmental factors which vary but little in place, time, and class of the population, and appear to be caused by fundamental influences which we neither understand nor are able to control. The second type consists of deaths mainly due to respiratory diseases and enteritis caused by the influence of the post-natal environment-overcrowding, atmospheric pollution, etc.-and probably entirely preventable. These two types of death overlap somewhat in time, but the end of the first month after birth provides a fairly sharp line of division. Some three-quarters of the mortality during the first month represents a bedrock loss of life which we have hitherto failed to reduce and which is mainly due to developmental conditions, while mortality after the first month is part and parcel of the general mortality of childhood, due to the same causes and demanding for its reduction the same measures.

Dr. Brend suggests that it might be of advantage to divide "infant mortality" into "birth mortality," the deaths during the first month, and "mortality of early childhood," the deaths from the end of the first month to the end of the third year.

In the second report Dr. Findlay discusses the causes of infantile mortality. He brings out the importance of environment (housing, etc.) as a factor in causing the present high infantile mortality, and he urges the need for a more scientific

1 "The Mortalities of Birth, Infancy, and Childhood." Medical Research Committee, Special Report Series, No. 1o, October, I9I7

2 In vital statistics the term "infant mortality" is used to denote he deaths of infants up to one year of age. 
investigation of the results following schemes of infant welfare if their true effects are to be determined. With regard to the latter, the danger of "overdoing it" is emphasised. For instance, in Poplar, in spite of an extensive infant welfare scheme in being, the infantile death-rate has risen. It is suggested that this disappointing result may be traceable to the people being harassed by a multitude of health visitors, which upsets them and makes them disinclined to adopt the measures urged upon them.

The third and final report is a statistical study by Dr. Brownlee of some of the data relating to infantile mortality. It is shown that the growth of the child is a continuous process from a period at least six months prior to birth up to the age of about four years, a process which is not interrupted either by the act of birth or by the act of weaning.

Certain disease conditions have also been investigated. Convulsions diminish in a perfectly definite manner from the age of two months to that of four years. In the group of premature births and wasting diseases some considerable saving of infantile life seems to be possible. The group of diarrhœal diseases is found to be a homogeneous statistical group, though it undoubtedly includes several distinct specific infections, from which it is inferred that the reason for the frequency of these diseases at the ages at which they occur must be sought for in the development of the child rather than in the type of parasite. Scarlet fever, measles, bronchitis, and pneumonia have also been investigated.

From the foregoing brief summary it will be seen that this report contains matter of much importance, and its appearance at this time is most opportune.

R. T. H.

\section{BARON DAIROKU KIKUCHI.}

BARON KIKUCHI, whose death took place on $B$ August I9, was one of the most conspicuous among the band of men who modernised education in Japan. He was born in Yedo (now Tokyo) on March $I 7,1855$, and came of a family of noted scholars. Both his father and grandfather were specially interested in Western learning, and Kikuchi himself early received a strong bias in the direction of scientific study. He was the youngest member of a small group of promising students whom the old Shogunate Government sent to Europe in 1866 . Owing to the revolutionary change of government which occurred in Japan in 1868 , Kikuchi was recalled home; but two years later he was again ordered abroad, this time to England. After some years spent at school he entered the London University College in 1873 , but ere long passed on to Cambridge, where he graduated as nineteenth wrangler in 1877 .

Returning home, he became professor of mathematics in the college where he had been himself a young pupil, which had developed gradually to the standard of a university. Originally known as the Kaisei-gakko, this school grew into what was NO. 2508 , VOL. IOO] afterwards known as the Tokyo University, and this in due course amalgamated with the Kobudaigakko, or College of Engineering, and became the highly organised Imperial University of Japan.

It was in the Tokyo University that Principal Sir J. A. Ewing, then professor of engineering and physics, carried out his well-known experiments on magnetic hysteresis; and associated with Kikuchi in these and later days were Edward Divers, professor of chemistry, C. D. West, professor of mechanical engineering, John Milne, the famous seismologist, as well as others, including the writer of this notice. Our intercourse with Kikuchi was marked with cordiality and mutual appreciation from the first, in great measure due, no doubt, to his experience as a schoolboy and student in London and Cambridge. He greatly admired the English genius for self-imposed discipline, and used to say that if he had not been a Japanese he would have desired above everything to be an Englishman.

From r88 r Kikuchi added to his professorial duties the office of the Dean of the College of Science, a highly responsible post at that time of strenuous educational development. As one of the members of the House of Peers under the new Constitution he was of great service in advancing various Bills of educational and economic importance, and rapidly established for himself a high reputation as a man of sagacity and administrative power. The mere enumeration of the public offices which he filled is a tribute to the confidence his fellow-countrymen reposed in him. In succession he held the posts of Vice-Minister of Education (1897-98), President of the Imperial University, Tokyo (1898-I901), and Minister of Education (I90I-3).

As one of the representatives of the Imperial Academy of Japan, he attended the meeting of the International Association of Academies at Vienna in 1907 , and thereafter spent a considerable time in this country. His course of lectures on Japanese education, delivered in that year under the auspices of the University of London, were published in English in Igog. This book contains the first systematic account of the history of education in Japan given to the world at large, and will ever remain a work of great value to the educational historian. A remarkably succinct sketch of the fundamental characteristics of the old Japanese civilisation, and of the way in which it proved itself equal to the absorption of Western learning, was given in an address delivered before the Royal Society of Edinburgh in June, 1907, and published in the Proceedings (vol. xxvii.).

After this stay in Europe, where Kikuchi renewed acquaintance with many former friends and made many new ones, he returned to Japan to take up again responsible educational duties. Up to the day of his last illness he was in the midst of all movements which were making for effciency in education. In March of this year, for example, he was appointed director of the newly established National Physico-Chemical Institute.

Called comparatively early in life to take a great 